\title{
THE STUDENTS' ABILITY TO IDENTIFY THE GENERIC STRUCTURE OF RECOUNT TEXT
}

\author{
Wiwik Yully Widyawati \\ Program of English Education, Faculty of Language and Art, University of Indraprasta PGRI \\ Jalan Nangka No. 58 C Tanjung Barat, Jagakarsa, South Jakarta 12530 \\ Wiwik121@gmail.com
}

\begin{abstract}
This research aims at analyzing the students' ability in identifying the generic structure of recount text, the problems and the solution of the problems faced by the students in identifying the generic structure of recount text. This research uses descriptive qualitative method. The research instrument is written test consisting of 10 items. There are 36 students are chosen randomly as samples. After the data have been collected and analyzed, the score of the students' ability to identify the generic structure of recount text is 73.9. It means that the students' ability in identifying the generic structure of recount text is fair. However, the problems faced by the students in identifying the generic structure of recount text are the students found the difficulty in understanding the meaning of the word and question, and they cannot identify the generic structure of recount text completely especially the part of event. Then, to overcome the problems, the writer offers some solutions, such as the teacher should give more exercises in analyzing the generic structure especially event. Moreover, the teacher should give more attentions to the result of the assignment given to the students.
\end{abstract}

Key words: genre, generic structure, recount text

\begin{abstract}
ABSTRAK
Penelitian ini bertujuan untuk mengetahui kemampuan siswa dalam mengidentifikasi struktur umum dalam teks recount, permasalahan dan solusi permasalahan yang dihadapi oleh siswa dalam mengidentifikasi struktur umum dalam teks recount. Penelitian ini menggunakan metode deskriptif kualitatif. Instrumen yang digunakan dalam penelitian ini adalah tes tertulis terdiri dari 10 soal. Teknik pengambilan sampling dipilih secara random sampling dan terpilih sebanyak 36 siswa sebagai sampel. Setelah data dikumpulkan dan dianalisis, hasil nilai dari kemampuan siswa dalam mengidentifikasi struktur umum teks recount adalah 73,9. Hal ini dapat disimpulkan bahwa kemampuan siswa dalam mengidentifikasi struktur umum teks recount cukup bagus. Namun, permasalahan yang dihadapi siswa tersebut adalah bahwa siswa mengalami kesulitan dalam memahami arti kata dan pertanyaan yang telah disajikan serta tidak dapat mengidentifikasi struktur umum teks recount secara lengkap khususnya pada bagian event. Kemudian, untuk mengatasi permasalahan tersebut, penulis memberikan beberapa solusi seperti guru sebaiknya sering memberi banyak latihan dalam menganalisis teks recount khususnya struktur umum pada bagian event. Selain itu juga guru memberikan perhatian yang lebih mengenai hasil dari tugas-tugas yang diberikan kepada siswa.

Kata Kunci : genre, struktur umum, teks recount
\end{abstract}




\section{INTRODUCTION}

In the curriculum, the students are also expected to be able to understand the kinds of texts. A text is semantic choice in social context (Martin, 2012). It depends on the context of situation. According to Macken (2010:6), "A text is a unit of meaning, which is coherent and appropriate for its context". Therefore, the purpose of texts is to tell someone how to do or to make something.

To understand how the texts work to make meaning, this in turn enables us to facilitate learners' interpretation and production of texts. The models of language connect between context and text. It means that the context of text is in a context of situation and in a context of culture. Relating to Gerot and Wignell (2012:10), "In the context of culture determines what we can mean through by 'being who we are', doing 'what we do', and saying "what we say". Context situation can be specified through the use of the register variables, field (what is going on), tenor (the social relationships), and mode (how language is being used).

By understanding the text, we can know the meaning of text and information. According to Gerot and Wignell (2012), there are three types of meaning to understand the text, namely: ideational meanings, interpersonal meanings and textual meanings. The text has to be cohesive relations to support the meaning of text. There are three systems to make the cohesion. There are semantics, lexico-grammatical, phonological, and orthographic. Cohesion is expressed partly through grammar and partly through vocabulary (Halliday, 2009).

In the 2004 curriculum, there are many kinds of texts. The kinds of text or types of text also called Genre. "Genre is a kind of text which each of text has the goal of communication, generic structure or schematic structure and language features" (Departemen Pendidikan Nasional, 2004). Genre is divided into two; they are story genre that it is a non factual text (such as narratives, news story, recount, spoof, exemplum, and anecdote) and factual genre that is factual text (such as procedure, explanation, report, exposition, discussion).

In learning genre, the students learn about three elements that supported it. First, improving their social function of communication by repeating and explaining the meaning of text. Second, improving generic structure ability by using dictionary and having a discussion with their friends. The last, improving significant lexico-grammatical features by scanning and skimming the text (Depdiknas, 2004). Each genre has different social function, generic structure and significant lexicogrammatical features.

According to Hornby (2010), generic means effecting all or most people place or thing. Therefore, generic structure is structure in text, which is usually used by learners in target language. In this research, the writer discusses the generic structure in the recount text. "Recount text is the text function to retell events for the purpose of informing or entertaining" (Yusak, 2010:13). The purpose of a recount text according to Anderson and Kathy (2011:48) is "to list and describe past experience by retelling events in the order in which they happened (chronological order)". There are three types of recount such as "personal, factual and imaginative recount" (Derewianka, 2009:20).

The generic structure of recount text is divided into three elements. They are orientation (giving the reader/listener the background information "who, what, 
where and when" to understand the text or providing the setting and producing participants), events (tell what happened, in what sequence) and re-orientation (optional-closure of events) (Yoseph, 2009). The problem of this research were first, students' ability in identifying the generic structure of recount text; second, problems faced by the students of seventh grade of SMPN 1 Mlonggo; third, solutions to the problems faced by the students seventh grade of SMPN 1 Mlonggo in identifying the generic structure of recount text.

\section{METHOD}

This research was categorized as descriptive qualitative research. Descriptive research, according to Gay and Airasian (2000:275) is "A study to determine and to describe the way things are". After that the writer took the sample randomly, 36 students. They were the seventh year of students SMP N 1 Mlonggo Jepara.

The data were taken by using observation and an essay test. The test consisted of 10 items and needed 60 minutes to do. Then, the writer gave them score. If the answer was correct, the writer would give it one score, and if it was wrong the writer would give them 0 score. The maximum score was 100 as amount of the items consist of 10 answers. After giving score and the data collected, the writer computed data by using the following steps:

1. Measuring the students' individual ability in identifyimg generic structure of recount text by using formula: score is the sum of the right answer divided by sum of items $x 100$ $\%$. After that, the writer counted the frequency distribution by using the following formula:

$\mathrm{P}=(\mathrm{F} / \mathrm{N}) \times 100 \%$

After getting the results statistically, then the writer consulted them to
Nurgiyantoro (2010) who uses five letters: A, B, C, D, and E that express various levels of achievement, as follows:

Table 1

The Level of Achievement

\begin{tabular}{lll}
\hline $\begin{array}{l}\text { The Percentage of } \\
\text { Level Achievement }\end{array}$ & Grade & $\begin{array}{l}\text { Level of } \\
\text { Achievement }\end{array}$ \\
\hline $85 \%-100 \%$ & A & very good \\
$75 \%-84 \%$ & B & good \\
$60 \%-74 \%$ & C & Fair \\
$40 \%-59 \%$ & D & Poor \\
$0 \%-39 \%$ & E & Fail \\
\hline
\end{tabular}

2. Measuring the mean of classical ability by using formula: Mean $(\mathrm{x})=$ $\Sigma \mathrm{x} / \mathrm{N}$. Then, to find out the problems which were faced by the students of seventh year SMPN 1 Mlonggo in identifying the generic structure of recount text, the researcher did some steps, those were:

a) The researcher analyzed the result of the test through some ways, those were:

- The researcher tried to find out the incorrect answer of the items of test that was done by the students of seventh year SMPN 1 Mlonggo.

- The researcher tried to find the reason why the students had mostly incorrect answer of each item.

The researcher observed the problems that might be faced by the students.

\section{RESULTS AND DISCUSSION}

After the data analyzed, the writer interpreted as follows:

1. Students' ability to identify the generic structure of recount text

a) Measuring the student's individual ability in identifying generic structure of recount text.

The classification of the category of the students' ability and their 
percentage could be seen in the table 2 below:

Table 2

The Classification of Each the Category of the Students' Ability in Identifying Generic Structure of Recount Text and Their Percentage

\begin{tabular}{ccccc}
\hline No & $\begin{array}{c}\text { Interval } \\
(\%)\end{array}$ & $\begin{array}{c}\text { Fr } \\
\text { eq. }\end{array}$ & Percent & $\begin{array}{c}\text { Cate- } \\
\text { gory }\end{array}$ \\
\hline 1 & $85 \%-100 \%$ & 8 & $22.2 \%$ & $\begin{array}{c}\text { very } \\
\text { good }\end{array}$ \\
2 & $75 \%-84 \%$ & 9 & $25 \%$ & good \\
3 & $60 \%-74 \%$ & 17 & $47.2 \%$ & fair \\
4 & $40 \%-59 \%$ & 1 & $2.8 \%$ & poor \\
5 & $0 \%-39 \%$ & 1 & $2.8 \%$ & fail \\
\hline
\end{tabular}

From the table above, it could be seen clearly that $22.2 \%$ or 8 students got very good mark, and $2.8 \%$ or 1 student got fail mark. In other description, $47.2 \%$ students got fair grade above. It meant that they had mastered reading skill in identifying the generic structure of recount text. However, $2.8 \%$ of students failed in mastered reading skill in identifying the generic structure of recount text.

b) Measuring the mean of classical ability

To calculate the mean, the writer arranged the score in frequency distribution that was a systematic arrangement of individual measurement from the highest to the lowest score. It could be seen in the table 3 below :

Table 3

The Frequency of Score

\begin{tabular}{cccc}
\hline No. & Score & Frequency & $\begin{array}{c}\text { Frequency } \\
\text { of Score }\end{array}$ \\
\hline 1 & 90 & 8 & 720 \\
2 & 80 & 9 & 720 \\
3 & 70 & 13 & 910 \\
4 & 60 & 4 & 240 \\
5 & 50 & 1 & 50 \\
6 & 20 & 1 & 20 \\
\hline \multicolumn{3}{c}{ Total } & $\sum \mathrm{x}=2660$ \\
\hline
\end{tabular}

From the computation above, the mean $(x)$ of the students score in identifying the generic structure of recount text was 73.88 . Then, the writer consulted it to the table 1 on the previous study which shows that the students' ability in identifying the generic structure of recount text could be categorized into fair.

2. The students' problems in identifying the generic structure of recount text.

To find out the problems which were faced by the students, the writer observed the answer sheet of the students. The writer found that some items which the students mostly answer them incorrectly, they were:

a) Item number 1

There were 2 students of 36 students answered incorrectly. Both cannot answer the question correctly because they cannot differentiate between orientation and event. They also had not understood about what orientation was.

b) Items number 2

There were 11 students of 36 students answered correctly. Most of the students couldn't answer question. They almost answered only 2 events, whereas, there were 3 events. It meant they didn't pay attention about generic structure that show event.

c) Items number 4

There were 8 students of 36 students answered correctly. It meant they didn't pay attention which sentences that belonged to 'event'.

d) Items number 5

There were 16 students of 36 students answered correctly. Most of them couldn't answer the question, but they answered "reorientation or yes" It meant they 
couldn't understand the meaning of the item (the word "what did" and "conclude").

e) Items number 6

There was 1 student of 36 students answered incorrectly. She answered incorrectly because she didn't pay attention about reorientation and didn't understand this generic structure.

f) Items number 8

There was 1 students of 36 students answered incorrectly. She couldnot answer the question correctly because she didn't identify the generic structure of the passage.

g) Items number 9

There were 7 students of 36 students answered incorrectly. They could not answer the question correctly because they didn't identify the generic structure belonged to event of the passage completely.

h) Item number 10

There were 5 students of 36 students answered incorrectly. They answered incorrectly as they did not understand this generic structure belonged to reorientation so that they did not identify it completely.

From the items above, the writer grouped them into two categories. Problems that might be faced by several students, they are:

a) Difficulty to understand the meaning. The students could not understand the meaning of the question (item number 5)

b) Difficulty to identify the generic structure. It meant that the student miss-organized paragraph (item number $1,2,4,8,9,10$ ).

To know the number of wrong answers, can be shown in the table 4.
Table 4

Percentage of the Items in Students' Wrong Answer

\begin{tabular}{cccc}
\hline No. & $\begin{array}{c}\text { About the } \\
\text { Items of } \\
\text { Identifying }\end{array}$ & $\begin{array}{c}\text { Number } \\
\text { of } \\
\text { Wrong } \\
\text { Answer }\end{array}$ & $\begin{array}{c}\text { Percentage } \\
\text { of Wrong } \\
\text { Answer }\end{array}$ \\
\hline 1 & Orientation & 3 & $5.9 \%$ \\
2 & $\begin{array}{c}\text { Event } \\
\text { Re- }\end{array}$ & 26 & $51 \%$ \\
3 & orientation & 22 & $43.2 \%$ \\
\hline
\end{tabular}

From the above table, the smallest percentage of the wrong answers was $5.9 \%$ telling about identifying the generic structure part of orientation. Therefore, identifying the generic structure part of orientation was more understandable than others. On the other hand, the biggest percentage of the wrong answers was $51 \%$ telling about identifying the generic structure part of event. Based on the analysis, the students could not identify the event than others because they do not understand the sequence of event in the text and miss-organized, so the students do not know how many events in the text. Therefore, identifying part of the events was less understandable than others.

3. Alternative ways to solve the problems

a) The teacher has to improve the teaching learning by using various media, give the students' motivation to seek more information theory by suggesting some supporting book to be read, help the students to overcome their problems or difficulties as soon as they made in order to be able to master the material well, give more attention to the result of the assignment, and give more exercises

To make a good ability in identifying the generic structure of recount text, the students have to: do more exercise, consult to the teacher 
about their problems which faced in understanding the material, and seek more information about recount text, especially the generic structure of recount text

\section{CONCLUSION}

After the data is analyzed, the writer draws some following conclusions. First, the students' ability in identifying the generic structure of recount text is fair. The mean of the students' score in identifying the generic structure of recount text is 73.9. Second, the problems which are faced by the students in identifying the generic structure of recount text are they couldn't identify the generic structure of recount text completely, especially the part of event, miss-organized the paragraph and missunderstanding the meaning of words and question. Third, the possible solution to solve the problems faced by the students are the teacher should give more exercises in analyzing the generic structure of recount text belongs to event, the teacher should apply all of things in the syllabi of genre in organizing the teaching learning process, and the teacher should give more exercises and more attentions to the result of the assignment which are given to the students in mastering the material. Whereas for the students, the researcher suggests to improve the English skill, especially in reading to support the developing knowledge of genre in general, especially on the generic structure of recount text by looking for or browsing the information in various media such as internet, reading books or other sources.

\section{REFERENCES}

Anderson, M., \& Kathy. (2011). Text Types in English. Australia: Macmillan.

Departemen Pendidikan Nasional. (2004). Kurikulum 2004 Standar Kompetensi. Jakarta.

Derewianka, B. (2009). Exploring How Text Work. Rozele, NSW: Primary English Teaching Association.

Gay, L. R. \& Airasian, P. (2000). Educational Research: Competencies for Analysis and Application. New Jersey: PrenticeHall.

Gerot, L., \& Wignell, P. (2012). Making Sense of Functional Grammar. Australia: Antipadean Educational Enterprises.

Halliday, M.A.K., \& Hasan, R. (2009). Cohesion in English. London: University College London.

Hornby, A. (2010). Oxford Advanced Learner's Dictionary. New York: Oxford University Press.

Macken, M. (2010). An Introduction to Genre-Based Writing. Australia: Literacy \& Education Research Network.

Martin, J. R. (2012). English Text System and Structure. 2Amsterdam: University of Sydney.

Nurgiyantoro, B. (2010). Penilaian dalam Pengajaran Bahasa dan Sastra. Yogyakarta: BFEYogyakarta.

Yoseph, B. (2009). Genre Based Writing. Semarang: UPGRIS.

Yusak, M. (2010). A Brief of Introduction to Genre. LPMP Jawa Tengah: Widyaiswara Madya. 